\title{
Ulusaşırı Göç ve Toplumsal Uyumda Din Eğitiminin Rolü: Erzincan Üzümlü'deki Ahıska Türkleri Örneği*
}

\author{
Doç. Dr. Ahmet Koyuncu \\ Necmettin Erbakan Üniversitesi, \\ Sosyal ve Beşeri Bilimler Fakültesi \\ Sosyoloji Bölümü \\ koyuncuahmet42@gmail.com
}

\author{
Uzman Sosyolog Rukiye Şimşek \\ r.simsek24@gmail.com
}

Öz

Adları genellikle sürgünlerle anılan Ahıska Türklerinin makus talihi 1829 Edirne Antlaşması ile Ahıska'nın Rus Çarlığına verilmesiyle başlamıştır. Stalin döneminden itibaren birçok kez sürgüne gönderilmişler, gerek vatanlarında gerekse sürgün bölgelerinde baskı ve zulme maruz bırakılmışlardır. Son olarak 2015 yılında Ukrayna'daki iç karışıklık ve çatışmaların ardından 7668 sayılı bakanlar kurulu kararı Türkiye'ye getirilen Ahıskalılar Erzincan Üzümlü ilçesine yerleştirilmişlerdir. Türk soylu ve Müslüman olsalar da her göç hadisinde olduğu gibi Ahıskalıların Üzümlü'ye uyum sürecinde de zorluklar ve sorunlar baş göstermiştir. Bu süreçte din, toplumsal kabulü kolaylaştırmada ve uyum sürecini hızlandırmada bir katalizör görevi üstlenmiştir. Bu çalışmada da dinin ve daha özelde din eğitiminin toplumsal uyum sürecindeki rolü Üzümlü'deki Ahıskalılar örneği üzerinden ele alınmıştır. Çalışma da Castles'ın kültürel ve sosyal uyum göstergelerinden yola çıkarak nitel yöntem, yarı yapılandırılmış mülakat ve katılımlı gözlem teknikleri kullanılarak elde edilen veriler söylem analizi yöntemi ile incelenmiştir. Araştırma sonuçları göstermektedir ki; din birliği ve özellikle de din eğitimi alınan ortam iki farklı toplumun kültürel uyum sürecinde önemli bir rol oynamaktadır. Ahıskalıların genelde Türk toplumuna özelde ise Üzümlü'ye olan aidiyetlerini din üzerinden kuruyor olmaları toplumsal uyum ve bütünleşmede dinin ve din eğitiminin önemini ortaya koymuştur. Benzer şekilde, yerli halkın Ahıskalılar ile ilgili yaşam tarzı farklılığı, devlet desteğiyle Ahıskalıların konutlara yerleştirilmeleri, İş-kur üzerinden işe başlatılmaları, kolay sunulan olanaklara kavuşmaları, fırsat eşitsizliğine sebep olmaları gibi olumsuz düşünceleri ve bu sebeple artan sosyal mesafe, din eğitimi sayesinde olumlu yönde değişim göstermiştir. Son olarak din eğitiminin toplumsal uyumdaki rolünün daha önce herhangi bir çalışmada ele alınmamış olması çalışmanın özgün değerini de ortaya koymaktadır.

Anahtar Kelimeler: Ahıska Türkleri, Erzincan-Üzümlü, göç, toplumsal uyum, din eğitimi.

\footnotetext{
* Bu makale, Doç. Dr. Ahmet Koyuncu'nun danışmanlığında tamamlanan Toplumsal Uyum ve Din: Erzincan Üzümlü'de Yaşayan Ahıskalılar Örneği başlılı Yüksek Lisans tezinden üretilmiştir. 


\title{
Transnational Migration and The Role of Religious Education in Social Adaptation: Example of Ahiska Turks in Erzincan Üzümlü
}

\begin{abstract}
The sinister fate of Ahiska Turks started with the 1829 Treaty of Edirne. They have been exiled many times since the Stalin era and subjected to oppression and persecution both in their homeland and in their exile areas. Finally, in 2015, after the internal turmoil and conflicts in Ukraine, Ahiskals were placed in Erzincan Üzümlü district. Even though they are Turkish nobles and Muslims, difficulty arose during the adaptation process of Ahiska people to Üzümlü as in any immigration. In this study, the role of religion and, more specifically, religious education in the social cohesion process was discussed through the example of Ahiskals in Üzümlü. Based on the cultural and social cohesion indicators of Castles, the data obtained by using qualitative method and semi-structured interview and participant observation techniques were analyzed by discourse analysis method. Castles' research shows that religious unity and especially the environment in which religious education is studied play an important role in the cultural cohesion process of two different societies. The social adaptation and integration of the Ahiska people as they establish their belonging to the Turkish society and to Üzümlü in particular, has revealed the importance of religion and religious education. Similarly, the negative thoughts of the local people towards the people of Ahiska, such as access to opportunities, inequality of opportunity, have changed positively through religious education. Finally, the fact that the role of religious education in social cohesion has not been addressed in any study before reveals the original value of the study.
\end{abstract}

Keywords: Ahiska Turks, Erzincan-Üzümlü, migration, social adaptation, religious education. 


\section{GİRIŞ}

İnsanlık tarihi ile eş zamanlı olan göç, değişen zamanların değişmeyen olgusu olmuştur. İnsanların farklı sebep ve amaçlarla bir yerden bir yere göç etmesiyle ortaya çıan yeni toplumsal ilişkiler, yeni siyasi ve iktisadi ilişkiler, yeni toplumsal örüntüler beraberinde toplumsal kabul ve toplumsal uyum tartışmalarına da kapı aralamıştır.

Göç gibi toplumsal uyum da toplumdaki tüm kesimleri kapsayan dinamik bir süreçtir. Nitekim göç eden bireyler göç ettikleri yerlere sadece fiziksel varlıklarını değil aynı zamanda kültürel birikimlerini de taşırlar. Başka bir ifade ile göçle gelen insan hareketliliği, gerek kendi yaşamlarını gerekse de ayrıldıkları ve vardıkları toplulukların yaşamlarını olumlu veya olumsuz biçimde etkilemektedir. Nitekim göç söz konusu olduğunda farklı kültürlerin, yaşam biçimlerinin karşllıklı etkileşimi gündeme gelmekte ve bu husus beraberinde toplumsal değişim ve toplumsal uyumu gündeme getirmektedir. Bu açıdan göç, bir neden sonuç ilişkisi bağlamında bakıldığında toplumsal dönüşümün birçok yönünü açıklayabilecek önemli bir süreçtir. Bir sonuçtur; çünkü politik, ekonomik, siyasal, kültürel ve toplumsal dönüşümün bir yansıması olarak çok sayıda insan, yerleşim yerlerini kimi zaman gönüllü olarak kimi zaman da zorunlu olarak değiştirmişlerdir ve değiştirmeye devam etmektedirler. Bir nedendir; çünkü bu insan hareketliliği, gerek kendi yaşamlarını gerekse de ayrıldıkları ve vardıkları toplulukların yaşamlarını olumlu veya olumsuz biçimde etkilemektedir. Göç eden birey(ler)in doğup büyüdüğü, eylemlerini gerçekleştirdiği, hatıraların biriktirdiği, kendini güvende hissettiği, bireyin imgesel yanına işaret eden ve varoluş hikayesine eklenen ana dizgeyi yani memleketini terk etmesi, farklı ve yeni bir toplumsal yapının, kültürün, yaşamın kapısının aralanması beraberinde hem göç edenler hem göç edilen toplumda değişimin habercisidir (Koyuncu, 2015, s. 231-232). Bu sebepledir ki, Schiefer ve van der Noll toplumsal uyum kavramını tanımlarken ortak aklı hedeflemek, sosyal ilişkiler ve ait olma hissi olarak üç temel boyuta vurgu yapmışlardır (2017, s. 581).

Konuya bu açıdan bakıldığında Ahıskaların Erzincan Üzümlü'ye göçleri de beraberinde toplumsal uyum sorunlarını gündeme getirmiştir. Ahıskalılar her ne kadar Türk soylu ve Müslüman olsalar da farklı bir coğrafyadan gelmeleri, bunun doğal bir sonucu olarak farklı bir kültürel tecrübe ve birikime sahip olmaları daha da önemlisi yarım asrı geçen sürgünleri, inanç ve kültürlerine yönelik asimilasyon politikaları dikkate alındığında toplumsal kabulün de kolay gerçekleşmeyeceği açıktır. Değil farklı bir coğrafya ve farklı bir kültür, iç göçlerde bile aynı ülkenin vatandaşlarının hatta aynı ilin ilçelerinden gelen hemşeriler arasında kültürel çatışmaların kaçınılmaz olduğu hatırlandığında Ahıska Türklerinin durumu daha net anlaşılacaktır. Nitekim Türkiye'de 1950'de kırdan kente ve 1980 'den sonra kentten kente yaşanan göçlerde ortaya çıan toplumsal kabul ve uyuma ilişkin sorunlar bu alanda zengin bir literatüre de zemin hazırlamıştır.

Toplumsal uyum son derece karmaşık, çok boyutlu ve süregiden süreçleri içerse de bu uyumu kolaylaştıracak temel bazı değişkenler de mevcuttur. Bu değişkenler arasında dil, etnisite, inanç birliği ve ekonomi en öncelikli temalar olarak karşımıza çıkmaktadır. Toplumsal uyum en basit ifadesiyle bir iletişim ve etkileşim süreci olduğu için dilin uyuma katkısı büyük bir öneme sahiptir. Göç edilen ülkenin ve bölgenin sosyal dokusunu, yerel halkın algılarını, beklentilerini, kültürel formlarını, gelenek, görenek örf ve adetlerini anlamak ve tüm bunları kendi kültürel tecrübe ve birikimi ile harmanlayarak toplumsal formasyona dahil olmak noktasında dil birliği öncelikli eşiklerden biridir. Bu anlamda, 
Ahıskalıların tüm baskı, zulüm ve asimilasyon politikalarına karşı dillerine sahip çıkmaları dil birliğinin bu uyum sürecinde önemli bir aktör olarak katkısına da imkan sağlamıştır.

Toplumsal uyumu kolaylaştıracak bir diğer değişken de göçmenlerin etnisiteleridir. Bireylerin aynı etnisiteye mensup olmaları, aynı millete aidiyetleri tarihin her döneminde birleştirici bir unsur olmakla birlikte 19. yy.'da imparatorlukların dağılmasının ardından ortaya çıkan ulus devletler etnisiteyi meşruiyetlerini ve sürekliliklerini sağlama noktasında en temel argüman olarak kullanmışlardır (Koyuncu, 2018a, s. 274). Bu bağlamda ulusal kimlik inşasında belirleyici unsur olan etnisite, toplumsal muhayyilenin anlam haritalarının şekillendirilmesinde öncü ve kurucu rol oynamıştır. Türkiye Cumhuriyeti de benzer bir tecrübeye şahitlik etmiş, ulus kimliği yeni devletin inşa sürecinde başat bir konum elde etmiştir. Bu husus ulusaşırı göçlerde de kendini göstermiş ve 1924 mübadelesinden bugüne Türkiye'ye yönelen ulusaşırı göçlerde Türk soylu göçmenler ayrıcalıklı bir konuma sahip olmuşlardır. Cumhuriyet döneminde Türkiye, farklı tarihlerde, farklı coğrafyalardan gelen çok sayıda göçmene, sı̆̆ınmacıya ya da geçici korumaya kapılarını açmıştır. Bu göçler içerisinde özellikle Türk soylu göçmenlere, Ziya Gökalp'in tek dil, tek kültür ve tek ideal esasından ilham alan ulus devlet nosyonunun bir yansiması olarak (Koyuncu, 2018b, s. 175) devlet tarafından uygulanan politikalar doğrultusunda barınma ve iş olanakları sağlanmış, çalışma şartlarının iyileştirilmesi amacıyla ayni ve nakdî yardımlar yapılmış, bu çerçevede çiftçi ailelere toprak, tohumluk, çevirme ve donatım kredisi; zanaatkar ailelere de konutun yanı sıra döner sermaye kredisi verilmiştir (Devlet Planlama Teşkilatı, 1990, s. 20). Özellikle Balkanlardan ve Kafkaslardan gelen bu göçmenlerin en önemli özelliği Müslüman olmalarının yanı sıra Türk ya da Türk soylu oluşlarıdır. Bu göçmenlerin büyük bölümü ya Türkçe konuşmaktadır ya da akraba dilleri konuşan topluluklara mensuptur. Türkiye söz konusu göçmenlere yaptığı yardımların yanı sıra vatandaşlık hakkı da tanımışır. Bu hakkın tanınmasında en önemli etken göçmenlerin Türk ya da Türk soylu olmalarıdır. Bu durum, Ahıska Türkleri içinde geçerlidir. Nitekim Erzincan Üzümlü'ye iskan edilen Ahıska Türklerine, yerli halkın yerleşmesi için planlanan ancak yerli halk fiyatlarını pahalı bularak yerleşmediği, TOKİ (Toplu Konut İdaresi) konutlarında 5 yıl süre ile ücretsiz ikamet imkanı sağlanmış, İş-Kur aracılı̆̆ıyla her evden bir kişi işe yerleştirilmiş, kaymakamlık tarafından yerel halkla aynı koşullarda seralar tahsis edilmiş, 5 yıl sonunda isteyenlere uygun koşullarda ikamet ettikleri evin mülkiyetini satın alma imkanı sunulmuş ve en önemlisi isteyenlere Türk vatandaşlığı verilmiştir.

$\mathrm{Bu}$ sayede göçmenler için toplumsal uyumda önemli bir eşik olan ekonomik sorunların da önüne geçilmiştir. Ahıska Türklerine sağlanan tüm bu imkanlar yerel halk tarafından çok da hoş karşılanmamış, özellikle TOKİ konutlarının ücretsiz tahsisi ve İş-Kur üzerinden işe yerleştirilme, fırsat eşitsizliğine sebep olduğu gerekçesi ile yerlileri rahatsız etmiştir. Bu durum, yerli halkın uyum konusunda gösterdiği direncin de temel sebepleridir. Söz konusu direncin toplumsal pratiğe yansıma düzeyini gösteren aşağıdaki örnek konuyu özetler niteliktedir.

$$
\begin{aligned}
& \text { "Illk zamanlarda yerli halk, Ahıskahlara tanınan imkanların da etkisiyle Ahıskalılara karşı } \\
& \text { oldukça mesafeli idi. Öyle ki, ilk zamanlarda kendi hayır hasenatları ile yaptırdıkları } \\
& \text { camiyi Ahıskalılar ile paylaşmak istemediler. O zaman müftü Bey devreye girdi de } \\
& \text { yerlilere kabul ettirdiler" (Din eğitmeni, H. G., 44). }
\end{aligned}
$$

$\mathrm{Bu}$ örnek, toplumsal uyumu kolaylaştıran değişkenlerden biri olan din ve inanç birliğinin toplumsal kabule etkisinin olumsuz bir yansıması gibi algılansa da tepkinin 
temelinde dinin değil seküler imkanların başat rol oynadığı gözden kaçırılmamalıdır. Burada tepkinin mekanının dinsel/kutsal bir forma sahip olması tepkinin dini olduğu anlamina gelmemektedir. Nitekim bulgular kısmında dinin uyuma olumlu etkisi bizzat katılımciların ifadeleri ile ortaya konmaktadır.

Bu bağlamda çalışmada Erzincan'ın Üzümlü ilçesine yerleştirilen Ahıska Türkleri ve yerel halkın birlikte din eğitimi aldıkları Kur'an kursları çalışma alanı olarak belirlenmiştir. Din birliği olan bu Türk soylu Ahıska Türkleri ve yerli iki halkın Kur'an kurslarında aldıkları din eğitiminin sosyo-kültürel hayata, toplumsal kabul ve uyuma etkileri belirlenen parametreler ışı̆̆ı̆ında incelenmiştir.

\section{TOPLUMSAL UYUMDA DINNIN VE DİN EĞITTIMININ ETKİSİ}

İnsanların var oluşundan beri din kurumu toplumsal yaşamın önemli yapı taşlarından biri olagelmiştir.

Bu bağlamda, dinin toplum yaşamında sosyo-kültürel bütünleşmeyi sağlama, toplumsal kontrol, toplumlara zihniyet kazandırılması, toplumun yeniden yapılandırılması gibi çok sayıda toplumsal işlevleri de bulunmaktadır. Toplumsal bütünleşme kapsamında din ve dine dayalı olan sosyal ahlaki sistemin önemli bir yeri bulunmaktadır (Sezen, 1990, s. 47). Bununla birlikte din, tüm zamanlar ve toplumlar için ayn işlevi görmeyebilir. Kimi zaman din toplumsal ayrışmanın ve çatışmanın da sebebi olabilir. Merton'un (1968, s. 105) bozuk işlev kavramı üzerinden ele aldığı bu konunun en belirgin örneklerinden biri (aynı dinin) mezhepler arasındaki çatışmalardır. Ancak bu çalışma bağlamında din, Ahıska Türklerinin toplumsal kabul ve uyumunda olumlu bir işleve sahiptir.

Konuyu göç, toplumsal uyum ve din bağlamında değerlendirdiğimizde dinin toplumsal uyum açısından önemli bir katalizör olduğu, toplumsal kabulü kolaylaştırdığı ve hızlandırdığı dikkati çekmektedir. Nitekim göç eden gruplar, göç ettikleri yerde toplumsal bir inşa sürecine girerler. Her ne kadar bu toplumsal inşa süreci içerisinde yerel halkla kurdukları ilişki belirleyici olsa da son tahlilde aradıkları şey anlam ve aidiyettir. Bu inşa sürecinde aranan anlamı ve aidiyeti sadece fiziksel çevreyle ve fiziksel mekanla ilişkilendirmek mümkün değildir. Bu bağlamda göçmenlerin anlam arayışında ontolojik bağlarının olduğu ve aidiyet duydukları din önemli bir kurumdur. Özellikle İslam dininde bizzat Peygamber (SAV) marifetiyle tesis edilen ensar ve muhacir kardeşliğinin inşa ettiği toplumsal formasyon ve bu akdin ortaya koyduğu değerler, normlar ve ritüellerin gündelik hayatın yeniden üretimi ve toplumsal düzenin imkanına sağladığı katkı toplumsal uyum ve uyumun parametreleri açısından önemli göstergelere sahiptir. Elbette bu kardeşliğin tarihsel süreçte nasıl bir dönüşüme uğradığı, günümüz Müslümanlarının bu kardeşliği nasıl algıladığı, nerede durduğu ve bu algının ürettiği toplumsal pratiğin gündelik görünümleri ayrıca tartışma konusu yapılabilir (Koyuncu, 2016, s. 518). Ancak İslam'ın ortaya koyduğu bu kavram setinin niteliği ve formu değişse de günümüz toplumunda hâlâ karşılık bulduğu da bir gerçektir. Başka bir ifade ile din kardeşliği faktörü kabulü kolaylaştırıcı, uyumu hızlandırıcı bir etkiye sebep olmaktadır. Bu durum, göçmenlerin kimlik oluşturma ve toplumsal inşa süreçlerinde belirleyici bir etkiye sahip olup, aidiyet duymalarına, toplumsal kabule ve uyumun kolaylaşmasına zemin teşkil etmektedir.

Takdir edileceği üzere, dinin toplumsal yaşamda tecessüm etmesi noktasında din eğitiminin rolü yadsınamaz. Bu açıdan ele alındığında din eğitimi veren kurumlar, bir taraftan dinin öğretilerini muhataplarına aktarırken aynı zamanda bir yaşam biçimini ve 
toplumsal kültürü yeni nesillere aktarma işlevi görür. Bu bağlamda din eğitiminin toplumsal uyum kapsamında önemi daha iyi anlaşılabilir. Dini kültür unsurlarının eğitim kanalıyla yeni nesillere aktarılması ve kültürün yaşatılması yanında bireylerin kişiliklerinin oluşumu ve gelişiminde de önemli rolü bulunmaktadır. Din eğitimi bu çerçevede yeni neslin bilinçlenmesi ve doğru bilgi alması açısından önemli bir işleve sahiptir. Dolayısıyla yukarıda dinin toplumsal kabule ve uyuma katsına ilişkin dile getirilen temel parametlerin içselleştirilmesi ve toplumsal pratiğe aktarılmasında din eğitiminin katkısı açıkça ortaya çıkmaktadır.

\section{AHISKALILARIN GÖÇLE İMTIHANI}

Araştırmanın yöntem ve bulgularına geçmeden önce Ahıska Türklerinin tarihsel süreçte yaşadığı sürgünler, asimilasyon politikaları ve Üzümlü'ye göç sürecine kısaca değinmek, verilerin ve yorumların daha anlaşılır kılınması açısından önem arz etmektedir.

Osmanlı son döneminde Kafkasya'nın Ruslar tarafından işgalinin ardından 14 Eylül 1829 tarihinde imzalanmış olan Edirne Antlaşması ile Ahılkelek ve Ahıska'nın Rus Çarlığına savaş tazminatı karşıllı̆ında verilmesiyle başlayan sorunlar Stalin döneminde Ahıska Türklerinin zorunlu tehcire maruz kalması ile sürmüştür. Trenlerdeki sığır vagonlarına bindirilerek Kazakistan, Özbekistan ve Kırgızistan'a sürgün edilmişlerdir. Binlerce insanın hayatını kaybettiği bu ilk sürgün 14 Kasım 1944 tarihinde gerçekleşmiştir. Ahıskalılar sürgünden sonra 12 yıl kamp yaşamını sürdürmüşlerdir. Stalin'in ölümünün ardından 1956 yılında Ahıskalıların Özbekistan'da geri dönüş mücadelesine girişmesine Sovyet yönetiminin sert müdahalesi ve Fergana'daki acı olayların ardından ikinci sürgün süreci başlamıştır. Sovyetleri Birliği'nin dağılmasıyla Ahıskalılar sorunu uluslararası arenada gündeme gelmiştir. Rusya Federasyonu'ndaki Krasnador eyaletinde yerel yöneticilerin yaptığı baskılar neticesinde zorda kalan Ahıskalılar, ABD'ye göç ederek üçüncü sürgünü yaşamışlardır (Üren, 2016, s. 1-3).

Üzümlü'deki Ahıskalılar da Fergana'daki baskı ve zulüme bizzat şahitlik etmişler ve bu elim olaylardan etkilenmişlerdir. Üzümlü'deki her Ahıskalının hafızasında Fergana olaylarına ilişkin acı hatıraların varlığı dikkat çekmektedir.

Ahıskalıların Türkiye'ye ilk kabulü ve iskanı ise 1992 yılındaki Bakanlar Kurulu kararına istinaden 1993 tarihinde gerçekleşmiştir. İlk 150 aile Iğdır'a yerleştirilmiş, sonraki 22 yıl boyunca Ahıskalıların göçmen olarak Türkiye'ye kabulü gerçekleşmemiştir.

Ahıskalıların Türkiye'ye ikinci göç dalgası ise Rus yanlılarının Ukrayna'da çıardığı iç karışıklık ve silahlı çatışmalardan sonra 2015 yılında gerçekleşmiştir. İlk önce Ukrayna'daki şiddetli çatışmalardan zarar görmüş olan 677 Ahıskalının göçü onaylanarak, 17 Mayıs 2015 tarihinde 7668 sayılı karar ${ }^{1}$ yürürlüğe girmiştir. Bu karar kapsamında 25 Aralık 2015'te Türkiye'ye getirilen Ahıskalılardan Erzincan Üzümlü ilçesine 595 aile, Bitlis Ahlat ilçesine de 82 ailenin yerleştirilmesi hususunda planlama yapılmıştır (Üren, 2016, s. 194). Daha sonra yaşam sürdükleri bölgenin çatışmalardan zarar görmesi nedeniyle 1200 Ahıskalı bölgeyi ziyaret eden Cumhurbaşkanı Recep Tayyip Erdoğan'ın talimatları ile Erzincan Üzümlü ilçesine iskanlı göçmen kapsamında yerleştirilmişlerdir (Fidan, 2016, s. 42). Üzümlü'deki Ahıskalılar ağırlıklı olarak Ukrayna'dan göç ile gelmişlerdir. Bunun dışında Azerbaycan,

${ }^{1}$ Bkz. Karar için: RG: 17.05.2015-29358 
Kazakistan, Rusya, Gürcistan ve yurt içinde Bursa ve İstanbul'dan gelerek Üzümlü’ye yerleşmiş Ahıskalılar da bulunmaktadır (Kaştan, 2015, s. 223).

Üzümlü'deki Ahıskalılar ağırlıklı alt-orta sınıf gelir grubuna dahildir. Pek çoğunun mülkiyetleri bulunmamaktadır. Yani mal varlıkları yoktur. Meslek dağılımları ise genellikle hizmet ve tarım sektörü üzerinedir. Üzümlü Kaymakamlığı'ndan alınan 2015 yılı istatistiksel verilerine göre ilçedeki Ahıskalıların yetişkin erkeklerin ağırlıklı lise mezunu, kadınların ortaokul mezunu olduğu görülmektedir. Türkçe okuma ve yazma yeterlilikleri ise düşüktür. Bu nedenle Üzümlü Kaymakamlığ tarafından düzenlenen Türkçe okuma yazma kurslarına katılım fazladır. Ahıskalılar ağırlıklı olarak Ukraynaca, Rusça ve düşük seviyede Özbekçe bilmektedirler.

Türkiye Cumhuriyeti devleti, Ahıskalıları "iskanlı göç" kapsamında kabul etmiş ve göç sürecinde herhangi bir filtre uygulamamıştır. Türkiye soydaş olan her Ahıskalıya talep etmesi halinde vatandaşlık vermektedir. Bu anlamda vatandaşlık alan Ahıskalılar Türk vatandaşlarının sahip olduğu tüm ekonomik, hukuki ve siyasal haklara sahiptirler.

Ahıskalılar kamu kurumlarındaki işlemlerini yapmak ve yasal işlemlerinin sürdürülmesi için Üzümlü Kaymakamlı̆̆ı'na bağlı olarak kurulan ve çalışanları Ahıskalı olan Ahıska Büro'dan faydalanmakta ve kamusal işlemlerini takip etmektedirler. Bunun yanı sıra 31 Mart 2019 yılında yapılan mahalli idareler seçiminde Ahıskalı bir kadının muhtar adayı olup muhtar seçildiği görülmektedir. Halen bu görevi yapmakta olan kadın muhtar Ahıskalıların sorunları ve beklentilerini yerel yönetimler bazında dile getirmekte çözümü için çaba harcamaktadır.

\section{YÖNTEM}

Araştırmanın konusu din eğitiminin Erzincan Üzümlü'ye göçle gelmiş olan Ahıskalıların sosyo kültürel hayata katılımına ve toplumsal uyuma katkısını incelenmektedir. Bu bağlamda gerek Ahıskalıların gerekse yerel halkın uyum sürecindeki ilişki ve etkileşim biçimleri, tarafların birbirileri hakkındaki kanaatleri, önyargıları, toplumsal pratiğe yansıyan tutum ve tavırlarının altında yatan saikler dikkate alınarak derinlemesine analizler yapma gerekliliğinden hareketle nitel yöntem tercih edilmiştir. Araştırma da veri toplama tekniği olarak yarı yapılandırılmış mülakat ve katılımlı gözlem kullanılmıştır. $\mathrm{Bu}$ yolla verilerin doğal ortamında ve mümkün olduğunca gerçekçi ve bütüncül olarak ortaya konması amaçlanmıştır.

Bilindiği üzere katılımlı gözlem, insan davranışlarını doğal ortamında gözlemleyerek daha doğru anlayabilmek içindir (Karasar, 2005, s.25). Bu bağlamda İlçe Müftülüguünden gereken izin alındıktan sonra 16 Ocak 2019 ve 06 Haziran 2019 tarihleri arasında her hafta Çarşamba günleri 09.00-12.00 saatleri arasında (her hafta bir kursa gidilmek suretiyle) belirlenen iki Kur'an kursunda, Ahıskalı öğrenciler ile yerli halktan öğrencilerin davranış ve tutumları doğal ortamında gözlemlenmiştir. Gözlemler ders aralarında da devam ettirilmiştir. Katılımlı gözlemde, araştırmacı örneklemini oluşturan toplulukla belirli bir süre zaman geçirmeli, sosyal aktivitelerde bulunmalıdır (Jackson, 1983: 40). Araştırmacılardan Rukiye Şimşek zaten bölgede ikamet etmekte olup, nişan, nikah gibi evlilik ritüelleri, düğün törenleri, bebek mevlidi, cenaze törenlerinde de katılımlı gözlem gerçekleştirilmiştir. Yanı sıra Ahıska Türklerinin evlerine misafir olunmuş, komşulara arasında düzenlenen günlere katılım sağlanmıştır. Gözlemcinin unutmadan, hızlı bir şekilde notlarını kaydetmesi önemli olduğundan her günün sonunda gözlem sırasında yaşananlar not edilmiştir. 
Yarı yapılandırılmış mülakatlarda ise Castles'a göre kültürel uyum göstergelerinden hareketle oluşturulan sorular (sohbet havasında) katılımcılara yöneltilmiş ve elde edilen bulgular katılımlı gözlem notları ile karşılaştırılarak söz konusu uyum göstergeleri bağlamında analiz edilmiştir. Bilindiği üzere katılımlı gözlem araştırmacının objektifliğini yitirme riskini de beraberinde getirmektedir. Bu sebeple gözlem notları, yarı yapılandırılmış mülakatlardan elde edilen verilerle karşılaştırılarak analiz edilmiştir.

Araştırma da uyum süreci, literatürde yer alan diğer çalışmalardan farklı olarak Castles tarafından alt başlıklarına ayrılmış, farklı kaynaklardan derlenerek bir araya getirilmiş olan, kültürel ve sosyal uyum göstergelerinden yola çıkılarak değerlendirilmiştir. Castles'a göre kültürel uyum göstergeleri, toplumun kültürünü tanıma ve değerlerini benimseme, toplum fertlerine duyulan güven ve yakınlık, aidiyet hissi ve dile hakimiyet; Sosyal Uyum Göstergeleri ise mekânsal ayrışma, kendi grubu içinde ve dişında sosyal etkileşim ve iletişim farklı gruplar arasında evlilik oranı (Castles, Korac ve Vertovec, 2002, s. 72) temaları üzerinden ele alınmaktadır. Castles ve arkadaşlarının belirlediği sosyal ve kültürel uyum alt göstergeleri incelediğimiz başlıklarla sınırlı değildir. Ancak çalışmanın konusu, örneklemi ve çalışma gurubu açısından sosyal uyum göstergelerinden dil öğrenimi ve dili kullanma becerileri (Ahıskalıların dili Türkçe olduğu için), ırkçı nedenlerle suça maruz kalma oranları ya da ırkçı nedenlerle suç işleme temaları (Ahıskalıların Türk soylu olmaları sebebiyle) dışarıda bırakılmıştır.

\section{Evren ve Örneklem}

Üzümlü ilçesinde Diyanet İşleri Başkanlığına bağlı olan, Ahıskalıların ve yerli halkın din eğitimi alabileceği altı adet Kuran kursu bulunmaktadır. Çalışmanın örneklemini Ahıskalıların ikamet bölgelerine yakın olan ve Ahıskalı öğrencilerin diğer kurslara göre daha fazla olduğu Fatih ve Geyikli mahallelerindeki iki Kur'an kursu oluşturmaktadır. Nitekim diğer dört kursta sadece birer Ahıskalı eğitim almaktadır. Fatih ve Geyikli mahallelerindeki kurslarda toplam 45 öğrenci bulunmaktadır. 5 öğrenci kurslara düzenli olarak devam etmemektedir. Fatih Mahalallesi'nde bulunan kursta derslere düzenli devam eden 20 öğrenciden 12'si yerli halktan 8'i Ahıska Türkü olup, Geyikli Mahalallesi'nde bulunan kursta derslere düzenli devam eden 20 öğrenciden 4'ü yerli halktan 16's1 Ahıska Türkü'dür. Nitekim Ahıska Türklerinin en yoğun olduğu mahalle Geyikli Mahallesi'dir. Öğrencilerin yaşları 21 ila 70 yaşları arasında değişmektedir. İki kursta toplam 4 din eğitmeni görev yapmaktadır. Gerek Ahıska Türkleri gerekse yerel halk (Şavaklılar) temel geçim kaynakları, gelir durumları, eğitim düzeyleri, kültürel formları itibariyle son derece homejen gruplardır. Araştırmacının bölgede ikamet etmesi ve araştırma kapsamında katılımlı gözlem yapılması da dikkate alınarak örneklem seçiminde amaçlı örneklem seçim tekniklerinden yoğunluk örneklemesi tercih edilmiştir. Bu sayede homojen bir grup içesinde araştırılan olguya ilişkin detaylı ve zengin bilgiye ulaşılması amaçlanmıştır. Bu kapsamda Fatih ve Geyikli mahallelerindeki iki kursa devam eden 10 Ahıska Türkü, 5 yerli halktan olmak üzere toplam 15 öğrenci ve iki din eğitmeni ile görüşülmüştür.

\section{Verilerin Analizi}

Araştırmadan elde edilen verilerin yorumlanmasında söylem analizi yönteminden faydalanmıştır. Söylem, temel olarak anlamı inşa eder ve böylelikle toplumlar mevcut semboller ve anlamlar arasında bağ kurar. Bu yolla toplumu oluşturan bireyler, konular, olaylar ve olgular üzerinde nasıl düşünecekleri ya da iletişim kuracakları söylemler üzerinden anlamlandırırlar. Bu araştırmada söylem analizinin tercih edilmesinde de elde 
edilen verileri açıklamak ve norm koymak değil anlama ve yorumlamaya yönelik okumalar yapma çabası belirleyici olmuştur. Nitekim söylem analizi bütüncül bir teori, metot ve uygulamadan ziyade farklı disiplinlerin teorik bakış açılarından beslenen ve yine bu disiplinlerin teorik görüşleri ile korunan, farklı araştırma geleneklerinin bir araya geldiği nitel bir araştırma yöntemidir (Tonkiss, 2006). Bu anlamda, söylem analizi, en basit anlatımı ile dilin incelenmesidir. Ancak bu inceleme sadece dilsel öğelerin basit bir incelenmesi olmayıp ifadelerin altında yatan alamı ve içeriği incelemeyi gerektirmektedir (Çelik ve Ekşi, 2008, s. 105). Van Dijk'in de (1997) ifade ettiği gibi söylem analizi, söylem ya da dil kullanımının sadece biçimsel yönü ile sınırlı değildir. Analiz, ilgi odağını sosyal ve kültürel bağlam içinde iletişim kuran dil kullanıcılarının oluşturduğu sosyal olaylara çevirir (Barker ve Galasinski, 2001).

Araştırmada, Castles'in sosyal ve kültürel uyum sürecinde ortaya koyduğu temel göstergelerden hareketle katılımcılardan elde edilen veriler söylem analizi ile analitik bir değerlendirmeye tabi tutulmuştur.

\section{AHISKA TÜRKLERİNIN TOPLUMSAL UYUMUNDA DİN EĞİTIMINNIN ROLÜ}

Farklı toplumların farklı örf ve adetleri, farklı bir dil ve söyleme sahip olmaları, farklı zaman ve mekân unsurları ile kayıtlı kalmaları aralarında bir kültürel farklılığın oluşmasına zemin hazırlar. Özellikle dil ve kültür bu konuda daha öncelikli rol oynayarak toplumsal farklılıklar sebep olur. Aynı şekilde iklim ve coğrafi yapının insanlar üzerindeki etkisi toplumlar arasında farklılıkları ortaya çıarır. Bununla birlikte kültürlerin ortak değerleri paylaşması noktasında etkili olan en önemli olgularından biri dindir. Bu husus aynı ortak inanç ögeleri ve değerlerin paylaşılması açısından kişi ve toplumların ortak bir payda da buluşmasını sağlayarak, ilişki ve etkileşimi daha kolay ve hızlı olmasına katkı da bulunur (Okumuş, 2006, s. 109).

Ortak dini ve kültürel değerler üzerinden, dini ve milli ortak bir bilinç oluşturmak toplumsal bütünleşmenin en önemli parametrelerindendir. Bu bilincin gündelik hayatta davranış biçimleri ile sergilenmesinde ortaya çıkan modelleri inceleyip anlamak adına Ahıskalılar ve yerli öğrencilerle yapılan mülakatlarda dinin toplumsal uyuma katkısı, Castles'ın kültürel uyum göstergeleri arasında yer alan toplumun kültürünü tanıma ve değerlerini benimseme teması kullanılarak analiz edilmiştir.

\section{Yerli Halkın Ahıskalı Algısı}

Her ne kadar Türk-soylu olsalar da farklı kültürlerde yaşamış olan toplumların uyum içerisinde yaşamlarını devam ettirmeleri çok büyük önem arz etmektedir. Yerli halkın da Ahıskalılar ile uyum içerisinde yaşamlarını sürdürebilmeleri için zihinlerindeki Ahıskalı algısını anlamak din birliğinin bu algıyı ne kadar etkilediğini görmek gerekmektedir. Bu algıyı anlamak için yerel öğrencilere yöneltilen "Ahıskalıları nasıl tanımlarsınız? Ahıskalı deyince zihninizde ne canlanıyor?" sorusuna verilen cevaplar şu şekildedir.

"Buraya (Üzümlü'ye) gelene kadar Ahıskal kim nerde yaşar hiç bilmiyorduk..." (Yerli öğrenci, R. G., 24).

İfadelerden de anlaşılacağı üzere yerel halkın, Ahıskalılara dair bir bilgilerinin olmadığı, Üzümlü’ye göçlerinden sonra Ahıskalıların kim olduğunu ve nereden geldiklerini öğrendikleri anlaşılmaktadır.

SEFAD, 2020; (44): 423-444 


\begin{abstract}
"Başlarda evlerde bedava oturmaları bizi rahatsız ediyordu, devlet bize onlar kadar sahip çıkmadı, adaletsizlik oldu, bizden de çok fakirler vardı hiç birisine iş-kurdan iş vermediler. Çok açlık çekenler oldu hala da var. Tabi ki başlarda çok karşıydık. Ve bu yüzden kızgındık ve tanışmak istemedik. Ama onları tanıdıkça bu fikirlerim değişti çalışkanlar ne iş olsa yaparlar evlerine ekmek götürmek için çalışıyorlar, evleri için de artık ya kira ödeyecek ya da satın alacaklar ve devlet bu kadar insanı savaştan bir şey vadederek getirdi diye düşünmeye başladık. Tanıdıkça sevdik, komşuluk yapıyoruz, artık buralılar gitmeyecekler anladık, zamanla daha çok kabul edeceğiz" (Yerli öğrenci, N. K., 45).
\end{abstract}

Yerel halkın Ahıskalılara dair algılarının şekillenmesinde öncelikli husus, devletin Ahıskalılara tanıdığı imkanlardır. Devletin Ahıskalılara ücretsiz konut tahsisi, ki bu konutlar yerel halkın ikamet etmesi için planlanmıştır, istihdam desteği sağlaması, tarımsal faaliyetleri için imkanlar sunması, kendileri de maddi sorunlar yaşayan yerel halkta tepkilere sebep olmuştur. Devletin kendi vatandaşı yerine dışarıdan göçle Ahıskalılara karşı imtiyazlı davrandığını, çok fazla fırsat verilerek yerli halk ile aralarında adaletsizliğe sebep olduğu dile getirilmiştir. Din eğitmeni H.G.'nin tespitleri de bu savı destekler niteliktedir.
“.... (yerel halkın) sıkıntıları ekonomik kaygılardan. En büyük sıkıntıları ise onlarm işlerini ellerinden alacă̆ı düşüncesi. Devletin oturdukları evlerini onlara ücretsiz verdiğ $i$ ve her aileden birinin iş-kur dan olan geçici olsa bile işe alınmalarmdan huzursuzluk duyuyorlar. Kendilerinin arazilerini evlerini kendi imkanları ile aldığını, kendi çocuklarının işsiz olduğundan yakınıorlar. Manevi olarak, kabullerinde sıkıntı yaşanmıyor daha çabuk uyum sağlıyorlar. Ancak olay günlük hayatta maddi konular olunca kabul düzeyleri düşüyor"(Din eğitmeni, H. G., 44).

Ahıskalıların yerleştirildiği Üzümlü'nün sosyo-ekonomik yapısının göçten önce de yerli halkın istihdam olanaklarına cevap veremeyecek düzeyde olduğu görülmektedir. Yerli halk ile Ahıskalılar arasında en temel sorun alanlarından biri işsizlik gibi ekonomik nedenler ile ilgilidir. Bununla birlikte karşılıklı ilişki ve etkileşim arttıkça, taraflar birbirini tanıdıkça tepkiler, zamanla yerini hoşgörüye bırakmış ve toplumsal kabulün önü açılmıştır. Bu kabul sürecinin sürecinin en önemli parametrelerden birinin de din olduğu katılımciların ifadelerinde açıçca görülmektedir.
"Buraya gelene kadar Ahıskalı kim nerde yaşar hiç bilmiyorduk. Çok eziyet çekmişler buralara da savaş olduğu için geldiler. Ama onlarda Türk ve Müslümanlar" (Yerli öğrenci, R. G., 24).
"Ahıskalılar gelecek dediklerinde bu kadar kalabalık olacaklarını zannetmemiştim. Bu bizi baya etkiledi. Türkçeyi bu kadar iyi konuşmalarına şaşırdım. Sonuçta Türk ve Müslümanlar, çok eziyetler çekmişler sürgünlerde. Çok çalışkanlar, temizler. Bazılarına göre kursa gelenler daha dindar ve anlayışlılar" (Yerli öğrenci, N. K., 45).

Yerli halktan öğrencilerle gerçekleştirişlen mülakatlar ve katılımlı gözlemler de yerel halkın tamamına yakınının Ahıskalılara dair bir bilgilerinin olmadı̆̆ı müşahede edilmiştir. Yerel halk, Üzümlü'ye geldikten sonra Ahıskalıları tanıdıklarını ifade etmişlerdir. Bununla birlikte hemen hemen tüm katılımcıların Ahıskalalılara yönelik algılarını şekillenmesinde etkili olan ve en önemlisi toplumsal kabulü kolaylaştıran iki temel unsur dikkati çekmektedir. İlki, Ahıskalıların "Türk ve Müslüman" oluşları, ikincisi ise sürgünlerde yaşadıkları baskı, zulüm ve eziyetlerdir. Başka bir ifade ile yerel halkın Ahıskalılara yönelik tanımlamalarından da anlaşılacağı gibi kabul düzeylerini dini referanslar üzerinden ortaya koymaları dinin toplumsal uyuma sunduğu katkının söyleme de yansıması bakımından 
kıymetli bir veri sunmaktadır. Dahası Kur'an kursuna gelenlerin daha dindar ve anlayışlı oldukları yönündeki açıklama da bir taraftan dine yönelik referansı pekiştirici söylemin, diğer taraftan din eğitiminin toplumsal kabul ve uyum sürecindeki olumlu işlevinin bir yansımasıdır.

Yerel halkın Ahıskalılara ilişkin kanaatlerinin şekillenmesinde Ahıskalıların yaşam tarzları ve gündelik hayatta dini pratikleri yerine getirme düzey ve biçimlerinin de etkili olduğu da görülmektedir.

\section{Dini ve Kültürel Değerleri Benimseme}

Ahıskalıların Üzümlü'ye göçlerinden sonra kültürel alanda yaşanan en temel tartışma gündelik yaşamda pratiğe yansıyan dini ve kültürel değerlerin çatışmasından kaynaklanmıştır. Nitekim göç, nüfus ve insan hareketliliğinin yanında, aynı zamanda yaşam biçimlerinin, inanç ve uygulamaların yeni yerlere taşınmasıdır. Bu çerçevede önceki yaşam biçimi yeni koşullar içerisinde sürdürülmeye çalışılırken öte yandan yeni şartlara da uyum sağlaması gerekmektedir. (Korkmaz, 2013 s. 367-368). Bu çatışmanın ortaya çıkmasında Üzümlü'de ikamet eden (özellikle de fiziki olarak Ahıskalılarla yakın temasta olan) ve kendilerini "Şavaklı" olarak adlandıran yerel halkın dini ve kültürel değerlere bakışı ve bu değerleri pratiğe aktarma biçimi oldukça etkilidir. 1940'lı yılların başında ekonomik sebeplerden Tunceli'den Erzincan'a aşiret olarak göç eden Şavaklılar Geyikli'ye yerleşmişlerdir. İlçenin genel ekonomisine hakim olan tarım ve hayvancilıkla uğraşmaktadırlar. Şafii mezhebine mensup olup, İslam dinini yaşama ve ibadetlerini ifa etmede Şafii mezhebine göre hareket etmektedirler. Kendilerini "ehli-sünnet ümmetten olan Şavaklı" olarak tanıtmaktadırlar. Sosyo-kültürel hayatta Üzümlü'nün hakim kültürüne uymakla birlikte yerel olarak kendi aralarında farklı geleneklerini de mevcuttur. Kısaca ifade edildiğinde muhafazakar bir kimliğe sahip olan Üzümlü halkı gündelik yaşamda da özellikle kıyafetler noktasında dini pratiklere önem vermektedir.

\footnotetext{
"Mesela bu kadar kalabalı Müslüman olmayan bir millet buraya gelse kesinlikle kabul etmezdik. Bizde yaşayamazdık. Bunlar biraz rahat giyiniyorlar diye sıkıntı çekiyoruz başka türlü olsa kesinlikle yaşatmazdık" (Yerli öğrenci, N. K., 45).
}

Din eğitmeni H.G. de ilk başlarda yerli halkın zihinlerinde Ahıskalılara karşı ortaya çıkan bu olumsuz durumu şöyle ifade etmektedir.
"Yerlilerde ki kabul Ahıskahllara göre daha yavaş gibi ilerliyor. Sosyal hayatta kültürel uyumda daha fazla rahatsılık duyduklarından bahsediyorlar. Özellikle yerliler Ahıskalıların giyimlerinin kültürlerine uymadığını, içki içtiklerini ve bunun günah olmadığııı düşünüyor oldukları onları daha rahatsız ediyor" (Din eğitmeni, H. G. 44).

Bununla birlikte dini ve kültürel değerlere uyum sağlamada Ahıskalılar üstün gayret göstermektedirler. Ahıskalılar, Kur'an kursunda eğitim almaya başladıktan sonra dinin nasıl yaşanacağını bilmediklerini görmüşler ve öğrendikçe yapmaya gayret etmişlerdir. Yerli halk ise göçün ilk zamanlarında kabul etmekte zorlandıkları Ahıskalıların uyum için gösterdikleri gayretten memnun olduklarını ifade etmektedirler.

\footnotetext{
“Ezanımız, Camimiz, ölümüz düğ̈̈nümüz bir. Din kardeşiyiz her şeyimizle bana bir şey olsa onlar üzülür onlara olsa ben bu dinimizdendir. Dinimiz olmasa bizi buralara almazlardı sevmezlerdi. Bizde istemezdik başka memleketleri Müslüman ata toprağ 1 diye buraya geldik. Gitmeyiz bir daha. Giyim, ibadet ve yeme (helal) içme (içki) konusunda çok değişiklikler oldu. Ukrayna'dayken daha rahattık ama bilmiyorduk dinimizin farklı şeyler
} 
istediğini. Müslümandık ama yaşayamıyorduk. Burada (Kur'an Kursunda) öğrendikçe daha çok yaşamaya başladık" (Ahıskalı Öğrenci, B. K., 64).

A. B. de kursta öğrendiklerini sosyal hayata aktarma, kurs ortamı ve dini kültürel yapının kendi hayatında yaptığı değişiklikleri şu şekilde dile getirmektedir.

"Namazın farzı, sünneti, bozanları bozmayanları oruç, ilmihal bilgileri gibi hepsini kursta öğrendiğim dinin kurallarına uyarak yapmaya çalışıyorum. Sadece tam olarak kapanamadım, onu da eşim istemiyor. Sana yakışmıyor diyor, zamanla oda değişir"(Ahıskalı Öğrenci, A.B., 28).

"Biz Müslüman olduğumuz için Ukrayna' da hep kendimizi farklı görürdük. Ama burada bizlerde sizlerde (yerliler) Müslümanız din kardeşiyiz. Bu yüzden daha çabuk alıştık, kabul ettik birbirimizi. Ahıskalı Ciminli'yiz diyoruz. Büyüklerimiz her nereye gittiyse Ahıskalıyız demişler. Bizde öyle yapacağız. Artık burada yaşıyoruz tabi ama Ahıskalıyız. Yeri geldiğinde Geyikli'liyim de diyorum" (Ahıskalı Öğrenci, M. T., 43).

Muhafazakar bir yapıya sahip olan Üzümlü'de Ahıskalıların dini pratikleri özellikle örtünme biçimleri (halaylık) ve kamusal alanda alkol tüketmeleri büyük tepkilere sebep olmuştur. Çünkü kendilerini Şavaklı olarak nitelendiren yerel halkın kadınları günlük hayatta yerel kıyafetleri olan şalvar ve üzerine "yaşmak" adı verilen ve ağızlarını da kapatan başörtülerinin üzerine uzun büyük bir örtü daha kullanmaktadır. Buna karşın Ahıskalıların halaylık olarak tabir edilecek örtünme biçimi ciddi tepkilere sebep olsa da özellikle Kur'an kursunda alınan din eğitiminin ardından Ahıskalıların dini ve kültürel değerlerin pratiğe aktarılması değişim gösterdikleri dikkati çekmektedir. B.K'nın “Giyim, ibadet ve yeme (helal) içme (içki) konusunda çok değişiklikler oldu. Ukrayna'dayken daha rahattık ama bilmiyorduk dinimizin farklı şeyler istediğini. Müslümandık ama yaşayamıyorduk. Burada (Kur'an Kursunda) öğrendikçe daha çok yaşamaya başladık" ifadelerinden de anlaşılacağı üzere Ahıskalılar uzun yıllar din eğitiminden uzak kalmıştır. Bu durum dini bilgilerin ve inanç ögelerinin süreç içerisinde farklılaşmasına da sebebiyet vermiştir. Örneğin yerel halk arasında büyük tepkilere sebep olan hatta kolluk kuvvetlerine yansiyan kamusal alanda alkol tüketiminin yine böylesi bir bilgi eksikliğinden kaynaklandığı görülmektedir. Nitekim Ahıskalılar sarhoş olunmadığı sürece alkollü içecekler tüketmenin helal olduğu bilgisi ile hareket etmektedir. Bununla birlikte Ahıskalıların Kur'an kursunda aldıkları din eğitimi sayesinde doğru bilgiye ulaştıkça daha önceki yanlış ya da eksik uygulamalarından vazgeçtiği görülmektedir. Ahıskalıların yıllarca doğru bildikleri ve gündelik hayatta kendine yer bulan kültürel pratiklerini din eğitimi ile çok kısa bir sürede bir kenara bırakmaları dinin Ahıska Türkleri için nasıl bir öneme sahip olduğunu ortaya koymaktadır. Bu husus, yerel halk tarafından da takdirle karşılanmış ve Ahıskalılara yönelik tepkilerin azalması ve toplumsal kabulün hızlanmasında önemli bir işlev üstlenmiştir.

"Gündelik hayatta çok dindar değiller. Hele tesettürlerine hiç dikkat etmiyorlar. Yaz olunca görmen lazım biz alışık değiliz, ilk geldiklerinde daha kötü giyiniyorlardı açık yerlerde, gündüz içki içiyorlardı. Yasak olduğunu bilmiyorlarmış meğerse. Kurstakilerle de konuşuyoruz onlarda zamanla düzeleceğini daha çok dikkat edip birbirlerini uyardıklarını söylüyorlar" (Yerli öğrenci, N. K., 45).

"Geldiklerine göre, öğrendikleri ve etraftan gördükleri için kendilerini değiştiriyorlar tabi. Kursa gelenler daha çabuk düzeltiyor kendini ve etrafindakileri. Rahatsız ediyor tabi açık giyinmeleri ve içki içmeleri. Kursa gelenlerde kendi tanıdıklarına kızıyorlar" (Yerli öğrenci, E. S., 33). 
Din eğitmeni A.T. bu durumu;

\begin{abstract}
"İlk başlarda Müslüman olduklarını bildikleri için karşılıklı kabul kolay oldu. Ancak dini bilgilerdeki eksiklikler ve bunun yaşamda ortaya çıkması kabul düzeyini düşürdü. Şimdi Kur'an'ı öğrenmeye açlar, sadece okumayı öğrenelim diye bütün güçlerini okuyabilmeye veriyorlar. Okumayı öğrenip anlama ve yaşama düzeyine geçtikleri zamanda Kur'an'ın evrensel barış dilini de çözmüş olacaklarına inanıyorum. Yerlilerde Ahıskalıların bu çabasın görüp takdir ediyor sabırla eksikliklerini gidermelerini bekliyorlar" (Din eğitmeni, A. T., 32) şeklinde ifade etmektedir.
\end{abstract}

Ahıskalılarda göçe zorlandıkları farklı bölgelerde tüm baskı ve asimilasyon politikalarına rağmen hakim kültürel değerleri benimsememiş kendi öz kültürlerinden kopmamışlardır. Bu sebepten kendi toplumlarının içine kapanmış, kapalı toplum olarak yaşamışlardır. Ancak bu zorunlu göç, Ahıskalıların "vatan" hasretlerini gidermekle kalmamış, kendilerini ait hissettikleri, özlemini duydukları sosyo-kültürel dini yapıyla buluşturması sebebi ile göçün ortaya çıkardığı dezavantajları fırsata dönüştürmüştür. Nitekim Ahıskalıların Üzümlü'ye göçleri dikkat çekici bir dönüşümün de habercisi olmuştur. M.T.'nin söylemlerine yansıyan "bizlerde sizlerde (yerliler) Müslümanız din kardeşiyiz. Bu yüzden daha çabuk alıştık, kabul ettik birbirimizi" ifadelerinin toplumsal kabule kapı araladığı ve göç edip geldikleri bölgelerde kapalı toplum özelliği gösteren, hakim kültüre direnç gösteren Ahıskalıların dinin etkisi ile tabir caiz ise gardlarını indirerek toplumsal uyuma yönelik bir çaba içine girdiği görülmektedir. Yine M.T.'nin söylemlerine yansıyan "Ahıskalı Ciminli'yiz diyoruz." İfadelerinde aidiyetin en üst perdeden vurgulandığ görülmektedir. Cimin, Üzümlü'nün eski adı olup, Ahıskalıların kendilerini Ciminli olarak tanımlamaları sadece Türkiye'ye değil yaşadıkları Üzümlünün tarihsel belleğine de aidiyetlerini ortaya koyması bakımından son derece manidardır. Köklerini yok saymadan (Ahıskalı-Ciminli) dile getirilen bu aidiyet algısı toplumsal uyum sürecinin sağlıklı bir biçimde gerçekleştiğini gösteren önemli bir veridir. Ahıskalıların özellikle din ve aidiyet bağlamında toplumsal uyuma yönelik tüm çaba ve istekleri yerel halkta da karşılık bulmaktadır. Bu nokta da Kur'an kursunda verilen din eğitiminin kabul ve uyum sürecinin en işlevsel kurumsal yapılarının başında geldiği de bizzat katılımcılar tarafından dile getirilmektedir.

Yerli halk da Ahıskalıların kendi kültürel değerleri benimsemelerini din üzerinden kurgulamakta ve din eğitimine verdikleri öneme dikkat çekmektedirler. Farklı ulusların içinde yaşamış olmalarına rağmen dini kimliklerini kaybetmemelerini, kendilerini Müslüman olarak tanımlıyor olmalarından memnuniyet duyduklarını ifade etmektedirler.

"Evet hocalarımı anlatyorlar peygamberimizin Yahudi komşularına bile saygll davrandığım söylüyorlar. Bizde, komşuluk dinimizde önemli diye daha hoşgörülü bakmaya çalışıyoruz. İlk başlarda daha sert düşüncelerimiz vardı" (Yerli öğrenci, R. G., 24).

Toplumsal uyumun sağlanmasında yakalanması hedeflenen uyuma katkı sağlamak için Kur'an kursları da önemli bir görev üstlenmektedir. Verilen din eğitimlerinde, kurs ortamında, sohbetlerde özellikle vurgulanan din kardeşliği, dinin komşuluk ilişkilerine vurgusu anlatılmakta, kurs içinde dini kandillerde, Cuma günlerinde yapılan karşılıklı küçük hediyeleşme programlarında toplumsal bütünleşmenin oluşmasına katkılar sunulmakta dinin toplumsal uyuma katkısı ortaya koyulmaktadır.

SEFAD, 2020; (44): 423-444 
"Kursa gelmeyen Ahıskalılarla hiç görüşmüyorum, görüşmekte istemiyorum. Onlar da Müslüman oldukların söylüyorlar ama yaşamıyorlar. Öğrenmek için kursa gelmiyorlar. Giyimleri helal haram algıları, içki kullanmaları kurstakiler gibi iyi değil. Kursa gelenlere oturmalara, düğ̈̈nlerde, hasta ziyaretlerinde, mevlüt, cenaze gidiyorum, diğgerleriyle hiç görüşmüyorum. Kursa gelenleri daha çok severim. Dinimizi öğrenmeye çalıştıklar için" (Yerli öğrenci, N. K., 45).

"Ukrayna'da dine açtık hasrettik şimdi öğrenmeye başladık. Dinin kuralların namaz, abdest, tesettür, ahlak, ilmihal tam olarak öğreniyoruz. Zamanla yaşayarak tam olarak yapmaya başladık. Kurstaki arkadaşlarımla daha samimiyim. Bilmediğimizi, yaptı̆̆ımız yanlışları bilmeden yaptı̆̆ımızı kursta daha iyi anlıyorlar" (Ahıskalı Öğrenci, K. G., 37).

“İlk karşılaşmamız kursta oldu sonra düğ̈̈nler, cenazeler, namazlar, iftarlar, sahurlar, mevlitler derken birbirimize benzeyen çok şeylerimiz var diye daha çok yakınlaşıyoruz. Kurs arkadaşlarım sayesinde onların diğer akrabalarn ile de komşuluk yapıyoruz yemekler, ders çalışıyoruz. Çocuklar birlikte ders çalışıyorlar" (Yerli öğrenci, E. S., 33).

Kültürel değerlerin benimsenmesi ve yaşatılması noktasında eleştiriler sadece yerel halktan Ahıskalılara yönelik değildir. Ahıskalılarda yerel halka yönelik eleştirilerde bulunmaktadır. Ahıskalılar da Üzümlü'de kültürel değerlerin bozulmuş olduğu, geleneksel aile yapısının (geniş aileden çekirdek aileye) dönüşmesi, boşanma oranlarının artması gibi hususlarda yerel halka tepki göstermekte ve duydukları rahatsızlı̆̆ı dile getirmektedirler.

"Sizde (yerli halk) Ruslaşmışsınız. Onlar gibi büyüklerinizden ayrılmış, başsız (yaşlısı olmayan) evlere yerleşmişsiniz. Başını olmazsa törenizi nasıl devam ettireceksiniz. Anneler ev işleri ile uğraşırken, törenizi, neneler çocuklara anlatacak, yaşatacak. Dinimiz bile büyüğüne hürmeti ve hizmeti nasihat etmektedir"(Ahıskalı Öğrenci, B. K., 64).

Ahıska Türkleri sürgün edildikleri farklı bölgelerde kültürel ve dini bağlarını kaybetmemek için din eğitimlerine çok büyük önem vermişlerdir. Aile büyüklerinin göç süreçlerinde kucaklarında saklayıp muhafaza ederek taşıdıkları dini kitaplardan sözlü aktarım yolu ile din ve kültür öğrenimini gerçekleştirmişlerdir.

Ahıskalılar geleneksel Türk aile yapısına sıkıca bağlı olup halen bu yapıyı korudukları için toplumsal huzur ve mutluluğun temelinin aileden geçtiğine inanmaktadırlar. Ancak genel olarak toplumda artan boşanma oranları, geniş ailelerin dağılması ve aile içi şiddetin artması sebebi ile özenle korudukları bu geleneksel aile yapısının bozulmasından endişe duymaktadırlar. Bu durumu, yerli halkla bağların oluşmasında, kültürel yapıya aidiyet ve karşılıklı dayanışmanın güçlendirilmesinde, sosyokültürel hayata katılımlarında, kısaca toplumsal uyum sürecinde kendilerini bekleyen bir tehlike olarak görmektedirler.

“Rusya'da korktuğumuz ama başımıza gelmeyen şey (boşanma) kendi vatanımızda başıma geldi. Buraya geldikten beri Ahıskalılarda şimdiye dek görülmeyen şey görüldü. 21 aile boşandr. Bu bizim için dinde, törede olmayan şey, biz bunun böyle olmasindan korkarız, kabul edemeyiz"(Ahıskalı Öğrenci, M. R., 55).

Ahıskalılar tarafından "21 aile boşandı. Bu bizim için dinde, törede olmayan şey" ifadelerine yansıyan ve yerel halka yönelik tepkisel bir tutum içine girilmesine sebep olmaktadır. Boşanmaların artma sebebi esasen uyum sürecinin bir yansımasıdır. Geçmişte Ahıska Türklerinde kesinlikle kabul edilemez olan boşanma, gerek ülke genelinde gerekse 
yerel de (talep edilmemekle birlikte) bir hak olarak görülmekte ve Ahıskalılar da bu süreçten payına düşeni almaktadır. Bu nokta da çalışmanın konusu ve amacı açısından önemli olan boşanma oranları konusunda da yine dinin referans alınıyor olması, dine yüklenen anlam ve dinin işlevsel etkisini bir kez daha ortaya koymasıdır.

Bu bağlamda Kur'an kurslarında İslam dininin aile içi mutluluğun toplumsal huzur için en büyük etken olduğunun naslar vurgulanarak öğretilmesi büyük önem arz etmektedir. Kurslarda verilen din eğitiminin, yerli halk ve Ahıskalılar arasında yaygınlaşması, zarara uğrayan bu sosyal yapıların onarılmasına katkıda bulunacağı düşünülmektedir.

Toplumun birlik ve beraberliğinin temin edilmesinde din merkezi ve en büyük etkendir. Bu durum ise Ahıskalı ve yerli halkın söylemleri analiz edildiğinde bir kez daha ortaya çıkmaktadır. Ortak dinler farklı kültürden gelen toplumlar üzerinde tutkal rolü üstlendiğinden, kültür ve medeniyet kimliği oluşturmakta toplumsal bütünleşmeyi sağlamakta, Ahıskalıların Üzümlü'deki sosyo-kültürel dini hayata uyumlarını kolaylaştırmaktadır.

Kur'an kursunda dini bilgileri öğrenmenin yanı sıra, kültürel ve sosyal aktivitelerin organizasyonu ve yürütülmesi, dini kimliğin yerleşmesi ve ibadetlerinin birlikte, doğru şekilde ifa ediliyor olması, kültürel aidiyet ve uyumun oluşmasına ortam sağlamaktadır. Önemli olan husus şudur ki, alınan din eğitimi davranış modellerine yansımakta ve sosyokültürel hayata aktarılmaktadır.

\section{Evlilik}

Castles'in sosyal uyum göstergeleri arasında yer alan farklı grupların karşılıklı evlilikleri, toplumsal uyum ve bütünleşmede önemli bir yer tutmaktadır. Nitekim evlilikler mevcut ilişkilerin akrabalık bağı ile daha da pekiştirilmesi, sosyal güvenin tesisi, kültürel uyumun pratiğe yansıyan en belirgin göstergelerinden biridir. $\mathrm{Bu}$ açıdan bakıldığında Ahıskalı ve yerli halk arasında da son yıllarda karşıllıklı evliliklerin gerçekleştiği görülmektedir. İlk olarak, eşleri vefat etmiş, orta yaşlı ve yaşlı bireyler arasında görülen evliliklerin son zamanlarda gençler arasında da (ilk evlilik) yapılmaya başladığı dikkati çekmektedir. Karşıllık evlilik yapan aileler ile gerçekleştirilen mülakatlarda, evlilik için ilk şartlarının din birliği olduğu, gerek Ahıskalı ve gerekse yerli halkın din üzerine vurgu yaptığı gözlemlenmektedir.

"Gençler kendi aralarında anlaştıktan sonra ben karşı çıkmam. Müslümanız. Dinimiz
izin veriyor sonuçta." (Ahıskalı Öğrenci, M. T., 43).

Yerli halktan olan ve Ahıskalı gelin alan kurs öğrencisi, karşılıklı düğün yapılmasının ilk sebebinin din birliği olduğunu şu şekilde ifade etmektedir.

\footnotetext{
"Müslüman olmasaydı gelinimin tarafı kesinlikle almazdım. Dinimiz komşuluğa çok önem veriyor, onların bizim üzerimizde hakları var. Birde aile birliğine çok önem veriyorlar saygllılar. Büyüklerine hürmetleri çok güzel. Onlarda Müslüman bizde en çok bu yüzden sıkıntı çıkarmadan buralarda birlikte yaşıyoruz" (Yerli öğrenci, F. M., 47). "Evlilikler oldu, olacak tabi bunun tek sebebi dinimizin bir olması. Tam yaşamıyor olsalar da dinin etkisi büyük"(Yerli öğrenci, Ş. D., 54).
}

Din eğitmeni A. T. iki toplum arasında karşılıklı yapılan evlilik için şu ifadeleri kullanmaktadır. 
“...Ilk duyduklarında tepkileri farklı oldu kabul etmediler. Ama zamanla gençler vazgeçmeyince bizlerde devreye girdik. Ayn dinden olmalar evlilik konusunda yumuşadıkları ilk yer oldu" (Din eğitmeni, A.T., 32).

Yukarıda da ifade edildiği üzere gerek Ahıskalılar (asimilasyona uğramamak için) gerekse Şavaklılar (aşiret yapısı ve mezhebi ve kültürel farklılık sebebiyle) kız alıp verme (evlilik) konusu başta olmak üzere kapalı toplum özelliği gösteren iki gruptur. Buna rağmen her iki grubunda dini referans alarak karşılıklı evliliklerin yolunu açmaları öncelikle dinin ve özellikle de din eğitiminin toplumsal uyma katkısı noktasında anlamlı veriler içermektedir. Yapılan mülakatlarda din birliğinin özellikle de Kur'an kursundaki birlikteliklerin, farklı kültür yapılarından gelseler de Ahıskalıları ve yerlileri bir araya getiren ortak değer olduğunu belirgin bir şekilde ortaya çıkmaktadır. Kur'an kursunda yakalan kardeşlik ruhunun, sosyo-kültürel pratik hayata aktarımı ile karşılıklı kabullerin arttığı, evliliklerin yapılmasının önündeki engellerin kaldırıldığı, toplumsal uyumu kolaylaştıran bir faktör olduğu gözlemlenmektedir.

\section{Mekânsal Ayrişma}

Bi başka sosyal uyum göstergesi olan mekansal ayrı̧̧ma genel bir bakışla "iki veya daha fazla grubun kent ortamının farklı bölümlerinde birbirinden ayrı yaşama derecesi" olarak tanımlanmaktadır (Massey, Rothwell, ve Domina, 2009, ss. 282-419). Üzümlü'deki mekânsal ayrışma ise temel de devletin iskan politikasından kaynaklanmıştır. Ahıskalıların Üzümlü'ye yerleştirilmelerindeki en önemli etken TOKİ'nin kullanıma hazır konut stoğudur. TOKİ'nin iskan alanı olarak daha önceden yerel halktan alıp kamulaştırdığı arazilere yapılan bu konutlar, ilk önce yerli halkın satın alıp yerleşmesi için planlanmıştır. Ancak yerli halk konut fiyatlarını pahalı bularak konutları satın alıp yerleşmemişlerdir. Devletin elinde kalan bu konutlara Ahıskalılar toplu ve iskanlı olarak göç ettirilmişler ve konutlar Ahıskalılara beş yıl süre ile bedelsiz verilmiştir. Bu uygulama ilk etapta yerli halkın Ahıskalılara ilişkin kanaatlerinde olumsuz bir etki meydana getirmiş, iki halk arasındaki sosyal mesafeyi artırmış ve toplumsal uyumun önünde önemli bir bariyer olmuştur. Ancak başta Kur'an kursu olmak üzere farklı mekanlardaki kültürel karşılaşmalar ve etkileşim bu algıların değişmesine imkan sağlamıştır. N.K'nın sözleri konuyu özetler niteliktedir.

"Başlarda evlerde bedava oturmalar bizi rahatsız ediyordu, devlet bize onlar kadar sahip çıkmadı, adaletsizlik oldu... Tabi ki başlarda çok karşıydık. Ve bu yüzden kızgındık ve tanışmak istemedik. Ama onları tanıdıkça bu fikirlerim değişti" (Yerli öğrenci, N. K., 45).

“Illk karşılaşmamız kursta oldu sonra düğ̈̈nler, cenazeler, namazlar, iftarlar, sahurlar, mevlitler derken birbirimize benzeyen çok şeylerimiz var diye daha çok yakınlaşıyoruz. Kurs arkadaşlarım sayesinde onların diğer akrabaları ile de komşu olduk. Yemekler yapıyoruz, ders çalışıyoruz. Çocuklar birlikte ders çalışıyorlar" (Yerli öğrenci, E. S., 33).

Ahıskalılarda mekânsal ayrışmanın toplumsal kabul ve uyumu geciktirdiği konusunda hem fikirdir.

"Ilk başlarda yerliler buralarda olsaydı daha samimi olurduk birbirimizle. En çok Ahıskalı komşular var ama ben yerli kurstan komşularla daha sık görüşürüm"( Ahıskalı Öğrenci, B. K., 64).

Katılımcı ifadelerine de yansıdığı üzere her iki grup arasındaki mekânsal ayrışmanın ortadan kalkmasında din eğitiminin önemi açıkça ortaya çıkmaktadır. Kuran kursunun 
mekânsal ayrışmanın beraberinde getirdiği sosyal mesafeyi azalttı̆̆ hatta bazıları için ortadan kaldırdığını din eğitimcisi H.G. de ifade etmektedir

“Şunu da gözlemliyorum ki kursta bulunmayan yerlilerle Ahıskalılar arasında kabul düzeyi daha düşük. Din Eğitiminin burada bulunuşlarının etkisi büyük. İlk kursa geldiklerinde ayrı ayrı oturup, ayrı çay molalarına çıkıyorlardı. Ancak çok uğraştık sohbetler, programlar, gezilerden sonra ikinci yılda bir arada olmaları gerçekleşti"( Din eğitmeni, H. G., 44).

Kısaca ifade edildiğinde, Kur'an kursunda iki tarafın bir arada arkadaşlık ilişkileri içinde bulunmaları, bu kurs arkadaşlık ilişkilerinin sosyal sermayeye olumlu yansıdığını ortaya koymaktadır. Ayrıca yerli halk ile Ahıskalıların gündelik hayatta farklı mekan ve sosyal ortamlarda kültürel karşılaşmaları arttıkça (temkin ve mesafe yerine) toplumsal uyumlarının arttı̆̆ gözlemlenmektedir.

\section{SONUÇ}

Göç olgusu menşei ülke gerekse hedef ülkelerrin toplumsal formasyonun ve toplumsal değişiminde önemli roller üstlenen bir katalizördür. Bununla birlikte özellikle ülkemizde ulusaşırı göçler ile ilgili literatüre göç olgusunun genellikle güvenlik ve ekonomi odaklı ele alındığı görülmektedir. Göçün bu şekilde ele alınması, devletlerin sınırlarına duvarlar örmesi ve diğer insani olguların göz ardı edilmesi açısından sorunludur. Göçün sorun odaklı tanımlanması, toplumsal uyumun da sorun odaklı görülmesini sağlar. $\mathrm{Bu}$ bağlamda, özellikle toplumsal uyuma yönelik çalışmalarda dinin toplumsal kabul ve uyuma etkisinin yeteri kadar tartışılmadığı an bir olgu olarak ortaya konmaktadır.

Erzincan Üzümlü'ye göç eden Ahıskalılar ile yerli halkın toplumsal bütünleşmesinde dinin etkisinin din eğitimi üzerinden ele alındığı bu çalışma öncelikle ilgili literatüre alternatif bir okuma imkanı sunma çabasının da bir ürünü niteliğindedir. Nitekim elde edilen bulgular, aynı dine mensup olmanın ve mensup olunan dinin evrensel barış dilinin, komşuluk, kardeşlik üzerine bütünleştirici vurgu yapmasının, toplumsal kabul ve uyumda son derece etkili olduğunu ve var olan ya da inşa edilen olumsuz algıları zamanla olumlu yönde değiştirğini göstermektedir. Göçmenlerin aidiyet bilincinin oluşması ve içselleştirilmesi, yerel halkın yeni ve farklı olana karşı dayanışma ve hoşgörü gibi değeri geliştirmesi, farklı kültürlerin bir araya gelmesinden kaynaklı kültürel zenginliğin gündelik pratiklere aktarılması ve tüm bu süreçte temel referans kaynağının din olması, toplumsal uyum noktasında dinin üstlendiği işlevin önemini bir kez daha ortaya koymuştur. Ahıskalıların genelde Türk toplumuna özelde ise Üzümlü'ye olan aidiyetlerini din üzerinden kuruyor olmaları toplumsal uyumda dinin önemini bir kez daha ortaya koymaktadır. Dinin söz konusu işlevinin ete kemiğe bürünmesinde ise din eğitiminin katkısı açıkça görüşmüştür. Tüm bu veriler göç polikalarının inşası noktasında politika yapıcılara da katkı sağlama potansiyeline sahiptir.

Bu bağlamda Üzümlü'de bulunan Kur'an kurslarında birlikte eğitim alan Ahıskalılar ve yerel halk bu eğitim sayesinde birbirilerini, kültürlerini, talep ve beklentilerini anlama fırsatı bulmuş, aldıkları eğitimin özellikle de din kardeşliği vurgusunun bir sonucu olarak yakın ve samimi ilişkiler kurma imkanına kavuşmuşlardır. Özellikle Ahıskalılar sürgün yılları boyunca hasret kaldıkları din eğitimine ulaşmanın sevinci ile büyük bir istekle kursa devam etmektedirler. Aidiyet duydukları İslam dinini doğru kaynaktan öğrenmekte ve öğrendikleri pratikleri sosyo-kültürel hayatta uygulamaya çalışmaktadırlar. Kur'an'ı 
öğrenmeyi, ibadetlerini doğru şekilde ifa etmeyi, yerli halka tanış olmayı ve uyum içinde yaşamayı sağladığı için Kur'an kursunda aradıkları anlamı bulduklarını ifade etmişlerdir. Bu sebeple din kardeşliğine ve eşitliğe vurgu yapan din eğitimini gündelik hayatlarında merkezi bir yerde konumlandırmışlardır. Bu durum, din eğitiminin toplumsal uyum açısından önemini ortaya koymaktadır.

Bu çalışma da ele alınan Ahıskalıların Türk soylu olması, ana dillerinin Türkçe olması, gerçekleşen göçün kitlesel olmaması, Ahıskalıların geldikleri bölgede de benzer meslekleri icra ediyor olması, ayrıca Üzümlü'nün imkanları ve yerel halkın muhafazakar bir kimliğe sahip olması gibi birçok etkenin sürece etkisi göz ardı edilmemek kaydıyla dinin ve din eğitiminin toplumsal kabul ve uyuma katkıları, göç politikalarının inşası noktasında politika yapıcılara da katkı sağlama potansiyeline sahiptir.

\section{SUMMARY}

Migration, concurrent with human history, has been the unchanging phenomenon of changing times. Ahiska Turks are among the first to come to mind when talking about migration. The sinister fate of Ahiska Turks started with the 1829 Treaty of Edirne. They have been exiled many times since the Stalin era and subjected to oppression and persecution both in their homeland and in their exile areas. Finally, in 2015, after the internal turmoil and conflicts in Ukraine, Ahiskans were placed in Üzümlü district in Erzincan province.

When the migration phenomenon is mentioned, the mutual interaction of different cultures and lifestyles comes to the agenda and this issue brings about social change and social harmony. The migration of Ahiskans to Erzincan Üzümlü has brought about social cohesion problems to the agenda. Although social cohesion involves extremely complex, multidimensional and ongoing processes, there are also some fundamental variables to facilitate this harmony. Among these variables, language, ethnicity, faith unity and economics are the top priority themes. Even though they are Turkish nobles and Muslims, difficulty arose during the adaptation process of Ahiska people to Üzümlü as in any immigration. In this process, religion has served as a catalyst in facilitating social acceptance and accelerating the process of adaptation. Religious education is one of the most important factors contributing to this adaptation process. In study, the role of religion and, more specifically, religious education in the social cohesion process was discussed through the case of Ahiskans in Üzümlü. The fact that the role of religious education in social cohesion has not been addressed in any study before reveals the original value of the study.

Based on the cultural and social cohesion indicators of Castles, the data obtained by using qualitative method and semi-structured interviews and participant observation techniques were analyzed by discourse analysis method. The study examined the relationship and interaction patterns of Ahiskans and local people, their opinions, prejudices and attitudes about each other. For this reason, qualitative method has been preferred for conducting in-depth analyses. Semi-structured interview and participant observation were used as data collection techniques.

Traditional rituals such as engagement, wedding, baby Mevlid and funerals of Ahiska people and local people have been studied through participant observation. In addition, attendance was provided for the days held among the neighbours. Semi-structured interviews were created based on Castles' cultural adaptation indicators. According to 
Castles, cultural adaptation indicators include the themes of recognizing the culture of the society and adopting its values, trust and closeness to the members of the community, sense of belonging and dominance of language. Themes addressed through indicators of social cohesion, on the other hand, are spatial decomposition, social interaction within and outside their group, and the ratio of marriage between different groups (Castles, Korac and Vertovec, 2002, p. 72). The sub-indicators of social and cultural cohesion identified by Castles and his friends are not limited to the titles we examine. However, considering the subject, sample and study group of the research, language learning and skills of language use (because the language of the Ahiskans is Turkish), crime exposure rates due to racist reasons or committing crime for racist reasons (due to the fact that Ahiskans are Turkish nobles) are excluded.

The sample of the study consists of two Quran courses in Fatih and Geyikli neighborhoods, where Ahiskan students are intensive in terms of population. In sample selection, density sampling, which is one of the purposeful sample selection techniques, was preferred. In this way, it is aimed to reach a detailed and rich information about the case investigated in a homogeneous group. In this context, interview was conducted with 10 Ahiska Turks, 5 locals, a total of 15 students and two religious educators who attended two courses in Fatih and Geyikli neighborhood.

In the study, the data obtained from the participants based on the basic indicators revealed by Castles in the social and cultural adjustment process were subjected to discourse analysis and analytical evaluation.

Castles' research shows that religious unity and especially the environment in which religious education is studied plays an important role in the cultural cohesion process of two different societies. The findings show that being a member of the same religion and the universal peace language of the religion to which one belongs have an integrative emphasis on neighborhood, fraternity, are highly effective in social acceptance and harmony and change the negative perceptions that exist or construct over time. Religion has contributed positively to the development and internalization of immigrants' sense of belonging, and the local people to develop value such as solidarity and tolerance towards the new and different. The transfer of cultural wealth resulting from the coming together of different cultures to everyday practices and the fact that religion is the main source of reference in this process has once again demonstrated the importance of the function assumed by religion at the point of social harmony. Ahiskans and local people, who were educated together in the Qur'an courses in Üzümlü, had the opportunity to understand each other, their culture, demands and expectations, and had the opportunity to establish close and sincere relations as a result of the education they received, especially the emphasis on religious brotherhood.

Briefly, the social adaptation and integration of the Ahiska people as they establish their belonging to the Turkish society and particularly to Üzümlü, has revealed the importance of religion and religious education. Similarly, the negative thoughts of the local people towards the people of Ahiska, such as access to opportunities, inequality of opportunity, have changed positively through religious education.

The process effect of many factors should not be forgotten such as the fact that the Ahiska people are Turkish nobles, their mother tongue is Turkish, the immigration is not mass, the Ahiska people perform similar professions in the region they come from and the 
local people have a conservative identity. Taking these considerations into account, the contributions of religion and religious education to social acceptance and harmony have the potential to contribute to policy makers at the point of building immigration policies.

Makale Bilgileri

Etik Kurul Kararı:

Araştırmanın Etik Kurulu Raporu vardır. (Onay kodu: 27.03.2020 /2020.07)

Katılımcı Rızası:

Araştırmaya katılanlara çalışmanın amacı ifade edilerek rızaları alınmıştır.

Mali Destek:

Çalışma için herhangi bir kurum ve projeden mali destek alınmamıştır.

Çıkar Çatışması: Çalışmada kişiler ve kurumlar arası çıkar çatışması bulunmamaktadır.

Telif Haklart:

Telif hakkına sebep olacak bir materyal kullanılmamıştır.

Article Information

EthicsCommittee Approval: The research has Ethics Committee Report (Approval: 27.03.2020/ 2020.07).

Informed Consent:

The purpose of the study is explained to the particants and their informed consent was obtained.

Financial Support:

Conflict of Interest:

The study received no financial support from any institution or project.

Copyrights: The authors declare that declare no conflict of interest.

No material subject to copyright is included. 


\section{KAYNAKÇA}

Barker, C., \& Galasinski, D. (2001). Cultural studies and discourse analysis: A dialogue on lnaguage and identity. London, UK: Sage.

Castles, S., Korac, M. Vasta, E. \& Vertovec, S. (2002). Integration: Mapping the field. Centre for Migration and Policy Research and Refugee Studies Centre, Oxford: University of Oxford.

Çelik, H. ve Ekşi H. (2008). Söylem analizi. Marmara Üniversitesi Atatürk Eğitim Fakültesi Ĕ̆itim Bilimleri Dergisi, 27(27), 99-117.

Devlet Planlama Teşkilatı. (1990). Bulgaristan'dan Türk göçleri, DPT Sosyal Planlama Başkanlığı Hizmete Özel Rapor. Ankara: Yazar.

Fidan, K. (2016). Kosova'daki Türklerin uyum meseleleri (Yayımlanmamış Yüksek Lisans Tezi). İstanbul Üniversitesi, Sosyal Bilimler Enstitüsü, İstanbul.

Jackson, P., (1983), Principles and problems of participant observation, Geografiska Annular, Series B, Human Geography, 65(1), 39- 46.

Karasar, N. (2005). Bilimsel araştırma yöntemi. Ankara: Nobel Yayın Dağıtım.

Kaştan, Y. (2015). Türkiye'de göç yaşamış çocukların eğitim sürecinde karşılaşılan problemler, Uluslararası Sosyal ve Eğitim Bilimleri Dergisi, 2(4), 216-229.

Korkmaz, A., (2013). Göç ve din, Mehmet Bayyiğit (Ed.), Din Sosyolojisi içinde (s.337-387), Konya: Palet Yayınları.

Koyuncu, A. (2015). Kentleşme ve göç. İstanbul: Hikmetevi Yayınları

Koyuncu, A. (2016). Ensar muhacir kardeşliğinden yerli sığınmacı dikotomisine toplumsal barış ve Suriyeliler gerçeği, II. Uluslararası Dini Araştırmalar ve Küresel Barış Sempozyumu Bildirileri içinde (s. 515-538), 19-22 Mayıs 2016, Saraybosna: Bosna Hersek.

Koyuncu, A. (2018a). Türkiye toplumunda Suriyeli sığınmacıların toplumsal kabulü ve dışlanması, Bilhan Kartal ve Ural Manço (Ed.), Beklenmeyen Misafirler: Suriyeli Sığınmacılar Penceresinden Türkiye Toplumunun Geleceği içinde (s. 271-294), London: Transnational Press London.

Koyuncu, A. (2018b). Misafirlikten vatandaşlığa Türkiye'de geçici koruma altındaki Suriyeliler. Middle East Journal Of Refugee Studies/MEJRS, 3(2), 171-195.

Massey D.S., Rothwell J., ve Domina T. (2009). The changing bases of segregation in the United States. The Annals of the American Academy of Political and Social Science, 626, 7490.

Merton, R., K. (1968). Social theory and social structure. New York: The Free Press.

Okumuş, E. (2006). Toplumsal değişme ve din. İstanbul: İnsan Yayınları

Schiefer, D. ve van der Noll, J., (2017). The Essentials of social cohesion: a literature review. Social Indicator Research, 132, 579-603.

Sezen, Y. (1990). Sosyolojide ve din sosyolojisinde temel bilgiler ve tartısmalar. İstanbul: İFAV

Şimşek, R. (2020). Toplumsal uyum ve din: Erzincan Üzümlü'de yaşayan Ahıskalılar örneği, (Yayınlanmamış Yüksek Lisans Tezi), Necmettin Erbakan Üniversitesi, Sosyal Bilimler Enstitüsü, Konya.

Tonkiss, K. (2006). Analysis text and speech: content and discourse analysis. C. Seale, (2nd ed.). In. Researching Society and Culture. (367-383). Lodan:Sage

SEFAD, 2020; (44): 423-444 
Üren, M., (2016). Kimlik, çıkar ve jeopolitik ekseninde Ahıska Türkleri sorunu. İstanbul: Nobel Bilimsel Eserler.

Van Dijk, T. (2003). Critical discourse analysis. D.Schiffrin., D. Tannen, \& E., H. Hamilton (Ed.), In The Handbook of Discourse Analysis. (352-372). Oxford: Blakwell Publishing. 